\title{
The Emergence of Ottoman Music and Local Modernity
}

\author{
Walter Feldman*
}

"The past per se is authoritative."

In his magesterial work, The Venture of Islam, this is how Marshall Hodgson characterized traditional, agrarianate cultures. ${ }^{1}$ That is to say, the past must be continually interpreted by a consensus of current authorities. Even cultural innovations must be justified in terms of the norms of the past. Thus it is not entirely surprising that many in republican Turkey still interpret the musical past according to a mixture of older and newer mythologies. There exist two current mythologies of the history of Ottoman music, an Ottoman one and a republican one. Both mythologies emphasize continuity over a very longue durée, with little meaningful historical change. The Ottoman myth had posited unbroken continuity from medieval Greater Iran (i.e. Herat to Istanbul) and from still earlier Baghdad. The republican myth (or rather myths) connected historically Turkic musical figures of the medieval Islamic civilization, such as al-Farabi (d. 950), Ibn Sina (d. 1037), and Maraghi (d. 1435) with the Ottomans, thus giving an unbroken "history" of one thousand years. Or else, by including a putative inheritance from pre-Turkic and pre-Islamic Anatolia and/or Mesopotamia, "Turkish" music has a "history" of three or four thousand years!

Taken together, these mythologies have impeded the progress of historical musicology within Turkey and they continue to keep Ottoman music on the periphery of intellectual interest outside of Turkey. However, once we go past the Ottoman and Turkish mythic histories, the picture that emerges from the existing sources-incomplete as they areshows both continuity with the past as well as some radical breaks. In order to attempt to understand these developments, we must look simultaneously at the musical situation at the Ottoman court, the central Safavid court in Iran, and the peripheral Safavid courts.

The relations of musicological issues to some current paradigms of Ottoman history and society were explored in the conference "A Locally Generated Modernity: the Ottoman Empire in the 'Long' Eighteenth Century," which I had organized under the auspices of NYU Abu Dhabi in February of 2018. While employing the historian Rifa'at Ali AbouEl-Haj's term "locally generated modernity" (from 1992), ${ }^{2}$ its full social and historical implications became more refined with a new generation of Ottoman historians after 2000, such as Edhem Eldem, Baki Tezcan, and Christine Philliou. For music the key portion of this period are the years roughly from 1670 to 1710 . And it is through this newer paradigm in understanding the "long" Ottoman eighteenth century that the broader implications of the musical theory of Prince Cantemir (ca. 170o) and of the music it was designed to describe can be better integrated. But first, we must turn to the preceeding historical period.

\section{Decline of the Late Medieval Persianate Musical Repertoire}

Several mecmua collections (poetic texts with makam, usul, and composers)-mostly of Ottoman provenance dating from the fifteenth to late sixteenth centuries-all use the Persian (or Arabic) language and the musical forms of Greater Iran, especially that of Khorasan, and its major city, Herat. This was a repertoire of "high prestige but limited

\footnotetext{
* New York University Abu Dhabi, walterzevfeldman@gmail.com

1 Marshall Hodgson, The Venture of Islam: Conscience and History in a World Civilization. Volume 1 (Chicago: University of Chicago Press, 1974), 109.

2 Rifa'at Ali Abou-El-Haj, “Theorizing Historical Writing beyond the Nation-State: Ottoman Society of the Middle Period," (unpublished paper 1992).
} 
diffusion, purveyed by specialists trained elsewhere."3 Despite the Turkic origin and Chaghatai language of the Timurids in Khorasan, this was a transnational Persianate repertoire that dominated the Ottoman court although there were earlier indigenous Anatolian Turkish musical developments (from Mardin to Konya). As the Ottomans became a world empire, with control of the old centers of Muslim civilization in the sixteenth century, the court displayed little interest in or support for Anatolian or Turkic musical practices. Under Süleyman I (1520-1566) even the international artistic repertoire was very little supported, despite the presence of his Iranian musician at court, Hasan Can. The 1565 literary tezkire of Aşı Çelebi (written toward the end of Süleyman's reign) placed great emphasis on the Turkish murabba and the türkü, rather than any of the "high prestige" Persianate vocal genres. Thus without integrating developments in Iran, it is extremely difficult to explain this musical shift within sixteenth-century Ottoman Turkey.

Herat in Khorasan had been the Timurid capital with an extremely high musical level. But during the sixteenth century artistic music was in decline in Safavid Iran. Fermans of Shah Tahmasp forbade music (from 1533 onward) - probably reflecting extreme Shiite viewssometimes ordering the execution of leading musicians. Artistic music survived better in the Iranian peripheries of Khorasan, Gilan, and the Caucasus (Erevan, Nakhchevan). In Central Iran art music gradually mixed with the popular music of the female courtesan musicians (qavval). Eskander Munshi, an important writer of early seventeenth-century Isfahan, distinguished between the khananda, whose repertoire included fixed compositions in long rhythmic cycles (usul), which he claims was strongest in Khorasan, and the guyanda, whose repertoire featured sung poetry to free rhythms. ${ }^{4}$ The latter was most characteristic of central and western Iran (i.e. the core Safavid territory) which was to become the modern Iranian state. This bifurcation prefigures the emergence of the avaz style of modern Persian art music in the nineteenth century within Iran proper (and in modern Azerbaijan) but not in most of historical Khorasan. This musical decline within the Safavid state was a protracted and uneven process. While it is true that Shah Abbas I (1588-1629) restored the royal patronage of music, by this time Iranian music seems to have been moving away from the earlier nawba suites and toward the more popular entertainment style propagated by the female courtesan musicians and dancers. The shift to a more populist repertoire was evident from the mecmua collection of Agha Momin, the Chalchi Bashi (chief musician) under Shahs Safi and Abbas II, who was in the royal service until $1655 .{ }^{5}$ The repertoire described there uses similar modality to what we see in the exactly contemporary Mecmua- $i$ Saz ü Söz of Ali Ufki Bey/Bobowski (1610-1675) in Istanbul. One generation later, Amir Khan Gorji's mecmua features Turkish popular forms, such as varsagi, which were apparently sung at court by Turkish speaking courtesans from the southern Caucasus. The fact that the older classical repertoire was preserved better in Gilan, Khorasan, and in the southern Caucasus proved to be extremely significant for the later history of music from Samarqand to Istanbul. Even as late as 1626, when the Transoxanian musician Mutribi Samarqandi visited the Timurid Mughal Emperor Jahangir, the latter was able to request a performance of a sawt-al 'amal in the complex rhythmic cycle nim-saqil, which had been composed a generation earlier, during the reign of Abdullah Khan in Bukhara (1583-1598) as well as even older and equally sophisticated rhythmic items created by Sultan Husein Bayqara and Mir Ali Shir Nava'i in late fifteenth-century Herat. ${ }^{6}$ The evident preservation of this complex repertoire in both Bukhara (as a part of "Khorasan") and Mughal India conforms with the developing distinction between metrically free and pre-composed metrical music within Iranian culture. The evident loss of the long rhythmic cycles (usul) after the middle of the eighteenth century in Safavid Iran, was a reliable marker for the end of the medieval musical era there. Thus the gradual decline of the complex composed genres in Iran, beginning in the sixteenth century, evidently led to their marginization within Ottoman Turkey.

At the Ottoman court of the late sixteenth-early seventeenth centuries we see a decline of the transnational Persianate repertoire in favor of more popular or folkloric songs of Turkic

\footnotetext{
3 Owen Wright, Words without Songs: A Musicological Study of an Early Ottoman Anthology and Its Precursors. SOAS Musicology Series

Volume 3 (London: Routledge, 1992), 285.

4 Amir Hosein Pourjavady, "The Musical Treatise of Amir Khan Gorji (c. 1108/1697)" (PhD diss., University of California, 2005$), 74$.

5 lbid., 130.

6 Richard Foltz, trans., Conversations with the Emperor Jahangir (Washington D.C.: Mazda Press, 1998).
} 
background: quasi-aşik and folkloric styles (türkü, varsagi, murabba). Primary sources are the two manuscripts of Ali Ufki Bey. Turkic stylistic elements appear somewhat later in some of the courtly repertoire attributed to Koca Osman, to Hafiz Post and to Ama Kadri. They are also found in the Third Selam of the Mevlevi Ayin (in the sama'i), and in some Halveti ilahis of the seventeenth and eighteenth centuries. They thus form a link between secular courtly and Sufi forms, which constitutes a very rich topic for possible future research. ${ }^{7}$

\section{The Ottoman Renaissance and non-Courtly Musical Agency}

A new Ottoman musical synthesis occurred around 1670-1710. From his Russian exile, Prince Cantemir wrote in his History in 1714: "[...] the Art of Music almost forgot, not only reviv'd, but also render'd more perfect by Osman Effendi a noble Constantinopolitan." This was Kasımpaşalı [Koca] Osman, and his students Hafız Post, Buhurizade Itri, et alia. Of course, Koca Osman was not entirely alone in this endeavor, but it is significant that Cantemir-whose teacher Buhurizade Itri was part of this musical "school"-chose to emphasize Osman's role. As I had suggested in 2015, ${ }^{9}$ it does not seem that Cantemir was attempting to create a new musical "mythology." Rather, he was simply interpreting the information that must have been imparted to him by his musical teachers concerning the situation of art music in the Ottoman capital in the generation prior to his birth. This musical revival-I had called it a "renaissance" in 2015-was not initiated by the Ottoman court but rather by aristocratic Muslims and Mevlevi dervish musicians. By the last third of the seventeenth century, the Ottoman Sultan Mehmed IV, and the Crimean Khan Selim Giray both patronized the leading Muslim composers, such as Hafız Post and Itri.

\section{Mehterhane, Long Usul Cycles and "Leisure": The Development of New Genres}

The evident breakdown in the transmission and new creation of the international "Persianate" courtly vocal repertoire in Istanbul between the second half of the sixteenth and the first half of the seventeenth century did not seem to have a similar effect on the instrumental repertoire. Unlike the courtly vocal repertoire, the instrumental genres peşrev and semai could not be described as having "high prestige but limited diffusion" due to one central factor-these genres were the basis for the official and public music of the Ottoman state, known as the mehterhane (or mehter) which was linked to the Janissaries. The instrumental genre known as "pishrow" was already a staple of the music of the Timurid court in fifteenth-century Herat - as it was mentioned in the Baburname ${ }^{10}$-but within Ottoman culture it became characteristic also of the military and ceremonial music of the mehter.

The earliest document of the newer phase of Ottoman music begins with the Hafiz Post Mecmuast (1666-1694), created during the reign of Mehmed IV. It displays only the "modern" repertoire centered on the murabba beste (first to be described by Cantemir in 1700) and utilizing long rhythmic cycles (usul). While such long usuls were known in several of the antecedent Iranian vocal genres, the murabba beste seems to fuse elements of these with the earlier Turkish murabba, which had been at times quite close to the folkloric türkü (with short usul forms). Bobowski shows a few examples that are transitional to the later style of murabba. ${ }^{11}$ Hafız Post rejected most of the folkloric genres (türkü, varsagi), except for the new urban şarkl, for which his teacher, the great poet Na'ili (d. 1666), composed lyrics.

\footnotetext{
7 Walter Feldman, Music of the Ottoman Court: Makam, Composition and the Early Ottoman Instrumental Repertoire (Berlin: VWB, 1996); "Structure and Evolution of the Mevlevi Ayin: The Case of the Third Selam," in Sufism, Music and Society in Turkey and the Middle East, ed. Olson Hammarlund, Tord Olsson, and Elisabeth Özdalga (Istanbul: Swedish Research Institute, 2001), 49-65.

8 Alexandra Dutu and Paul Cernovodeanu, eds., Dimitrie Cantemir: Historian of South East European and Oriental Civilizations (Bucharest: Association Internationale d'Études du Sud-Est Européen, 1973).

9 Walter Feldman, "The Musical 'Renaissance' of Late Seventeenth Century Ottoman Turkey: Reflections on the Musical Materials of Ali Ufki Bey (c. 1610-1675), Hafız Post (d. 1694), and the 'Maraghi' Repertoire," Writing the History of Ottoman Music, ed. M. Greve (Würzburg: Ergon Verlag, 2015), 87-138.

1o Feldman, Music of the Ottoman Court.

11 For long usuls, see Feldman, "The Musical 'Renaissance."
} 
176 Although the official mehter was an outdoor wind, brass, and percussion ensemble, there was considerable crossover between the 'official' military peşrev and the indoor courtly peşrev. Indeed without this 'crossover' between 'official' outdoor and artistic indoor instrumental music, it is doubtful that Bobowski, Cantemir or Nayi Osman Dede (1652?-1729) would have notated their collections, as none of these musicians were involved with the mehter per se. One of the most outstanding 'crossover' musicians was Hemdemi Mehmed Çelebi, usually referred to as 'Solakzade' (d. 1658). He stemmed from a Janissary origin but became both a musician and a painter (nakkass), a poet, as well as a historical writer. With such an array of talents, he was chosen to be a boon-companion (nedim) of Murad IV (1623-1640). Solakzade's primary instrument was the miskal, or panpipes. Nevertheless, his peşrev compositions were performed by the official mehter ensemble. During the early seventeenth century in Istanbul, long usuls were preserved by the official mehterhane far better than in courtly music. "Crossover" mehter musicians, such as Solakzade, playing courtly instruments, transferred the peşrev to the courtly environment together with Mevlevi musicians such as Çengi Yusuf Dede. ${ }^{12}$ Composers such as Koca Osman and Hafız Post evidently incorporated the long usul form into vocal music, thus creating the murabba beste. They also sought out living Iranian sources for the Persian courtly repertoire (kar, nakiş) and created new pieces based on older Persian models.

We can see the influence of Mevlevi dervishes in secular art music, as the Mevleviye became more centered in the Ottoman capital during the seventeenth century. Of the three outstanding teacher/composers of this generation, two were Mevlevi dervishes-Çengi Yusuf Dede (d. 1670), Köçek Mustafa Dede (d. 1683) as well as the secular aristocrat Koca Osman Efendi. The short treatise of Çengi Yusuf Dede (ca. 1650) shows a full compendium of usuls. During the course of the eighteenth century these usuls would show a process of expansion along with an evident decrease in tempo. Some of this is already seen in the musical treatise of Charles Fonton from 1751, who was a contemporary of the great composers Zaharya Hanende, Kemani Corci, and Tanburi Haham Musi. Rauf Yekta Bey had noted something of this structural change already, ${ }^{13}$ but its full significance was only elaborated upon by Owen Wright ${ }^{14}$ and more recently by the present author. ${ }^{15}$ This "rhythmic retardation" and "melodic expansion" (to use Wright's phrases) altered the surface and even the deeper compositional structure of both vocal and instrumental music. As Wright had demonstrated, the later Ottoman tradition could not tolerate the earlier, shorter forms of the long usul, with their more obvious connection of melodic and rhythmic structure. Thus the entire early peşrev repertoire was "recomposed" to conform to later musical usage. The vocal repertoire may not have been reworked as drastically, but this remains to be demonstrated. Likewise, the Mevlevi ayin repertoire does not reveal such a high degree of recomposition. ${ }^{16}$

No doubt several social and cultural factors were at work in this reconceptualization of rhythm and tempo. In a recent talk Harun Küçük stressed the concept of 'leisure' (rahat) as a cultural factor, "...as a perception of time, as a state of being, and as a moral disposition." In his historical view, the greater prosperity and political stability of the eighteenth century pushed to the fore the concept of leisure as a cultural value, loosely comparable to the 'otium' of the ancient Romans and was conceptualized as such by writers such as Mavrocordato. In addition, the new participation of Greek Orthodox composers at the Ottoman court and even the evident incorporation of Byzantine musical features by Turkish composers-the locus classicus being the Rast Naat-l Peygamberi by Buhurizade Mustafa Itri in the 1680smust be considered as part of a broader interpretation of the new musical style.

12 Çengi Yusuf Dede, Risale-i Edvar, ed. Recep Uslu (Ankara: Çengi Yayınevi, 2015).

13 Rauf Yekta, Mevlevî Ayînleri, v.2 (Istanbul: İstanbul Belediye Konservatuar1, 1924), 285.

14 Wright, Words Without Songs.

15 Walter Feldman, "The Art of Melodic Extension within and beyond the Usul," in Rhythmic Cycles and Structures in the Art Music of the Middle East, ed. Zeynep Helvac1, Jacob Olley and Ralf Martin Jaeger (Würzburg: Ergon Verlag, 2017), 154-176.

16 Walter Feldman, "Structure and Evolution of the Mevlevi Ayin: The Case of the Third Selam," in Sufism, Music and Society in Turkey and the Middle East, ed. Olson Hammarlund, Tord Olsson, and Elisabeth Özdalga (lstanbul: Swedish Research Institute, 2001), 49-65. 17 Harun Küçük, "Leisure in Eighteenth Century lstanbul" (Lecture, NYU Abu Dhabi Institute, NYC, January 29, 2019). 
The emergence of modern Ottoman music was symbolized by the new instrumentarium: the tanbur (long-necked lute) and the ney (reed flute). The combination of these two instruments, of Turkic and Sufi origin respectively, are unique to Ottoman Turkey. The medieval oud, şahrud, kopuz, and çeng were eliminated by the last third of the seventeenth century (reign of Mehmed IV). What the tanbur and the ney have in common is the extreme volatility of their system of overtones, plus their natural preference for slower tempos. Neither of them is constructed for the display of virtuosity. Thus their elevation suggests a new and very specific musical aesthetic. We might summarize the musical and cultural significance of the development of the new Ottoman tanbur with the following three points:

a. The tanbur featured the resonance and overtones of long-necked lutes, which are impossible to achieve with short-necked lutes. The extremely active overtone system of the tanbur is in keeping with the widespread and ancient Turco-Mongolian preference for 'timbral' musical expression in addition to a pitch-centered system. ${ }^{18}$

b. Urban Turkic cultures of Central Asia had used long-necked lutes (also called tanbur) since the Uyghur period. This may have further reflected a Turkic preference for playing the entire melody on one string (or two unison strings), as opposed to breaking up the melody between two or more strings on a short-necked lute.

c. The very long neck and the long hard plectrum of the Ottoman tanbur limits agility, thus leading to a preference for slower and more ponderous tempos-in which the instrument's overtones could be clearly perceived-that came to characterize Ottoman music during the eighteenth century.

At the same time the courtly formal concert (fasl-ı meclis) reasserted itself, with fixed positions for the ney and the tanbur within the ensemble.

\section{The Pseudo-Maraghi Corpus and the Ottoman Musical Renaissance}

The position of art music in the Safavid court became somewhat stronger during the second half of the seventeenth century, as seen in the treatise of Amir Khan Gorji. ${ }^{19}$ In this treatise, compositions attributed to the great medieval composer and theorist Abd al-Qadir Maraghi (d. 1435) are regarded as a musical model. These compositions may perhaps have had some continuous history in Iran.

At the same time, as the Ottoman musical renaissance unfolded in Istanbul, a new pseudographic repertoire under the name of Maraghi/Meragi made its appearance. It is now documented in the Hafiz Post Mecmuast and thereafter. For the first time, Maraghi is the "teacher" (hoca), and every fastl usually begins with a composition or two of his. In the following generation, Prince Cantemir refers to the "Hodja Musicar," without naming Maraghi as a historical figure. Thus Cantemir attempts to balance an actual history of local musical development-as revealed to him through the line of the students and associates of Kasımpaşalı Osman - with an Ottoman mythic history being developed in the previous generation, in part by some of these same musicians. While the writings of the great medieval theorist Maraghi were familiar to the Ottomans, the existence of surviving repertoire seems to have been little known to Ottoman musicians of the first half of the seventeenth century, such as Bobowski or Evliya Çelebi, who fail to mention him in their writings. While some sixteenth-century Istanbul Greek sources show an awareness of a vocal repertoire associated with Maraghi, the elevation of this medieval composer to almost mythic proportions did not occur in the Ottoman Empire prior to the last third of the seventeenth century. The prominence of Maraghi as a reputed model for the compositions of the Iranian Amir Khan Gorji-who was Hafız Post's contemporary-raises the possibility 
178 that his reputed 'compositions' became available rather suddenly to Ottoman musicians of their generation. The currently known repertoire of Maraghi has been shown by Wright to be stylistically not older than the earlier seventeenth century. ${ }^{20}$ Thus this rather recent Iranian repertoire symbolized 'continuity' with the past, precisely when there was little such continuity. It was a strategy by which a basically oral musical culture could renew and recreate itself, while still pointing to its links with an older 'Great Tradition.'

\section{Notation}

During most periods of the Islamic civilization - with certain exceptions-the writing down of musical notes was viewed as auxiliary to a theoretical analysis, not as an end in itself. As stated by the early Ottoman musicologist Seydi in 1504: "All other sciences are written down and everyone has studied them/but there was no way to write down this science." The ambivalence of the Ottoman Muslim musicians toward notation stemmed first of all from the conditions of musical pedagogy known as meşk, in which the broader issues of articulation, tempo and phrasing were acquired by imitation of the teacher. Musicians who had learned the compositions orally were in a much better position both to compose new items in these genres and to be able to communicate the structure of older pieces. This knowledge survived at the interface of kinetic, musical and analytic understanding. After having learned a complex item in this slow and painstaking manner, most musicians saw no point in creating a reduced version in any form of musical notation. Ottoman musicologists like Seydi felt-perhaps somewhat like twentieth-century Russian musicologists such as Boris Asafiev and Izaly Zemtsovsky - that much of the essence of music lies in its articulation during performance, which cannot be adequately transcribed into notation.

Starting around 1700, the Ottoman Empire became the first Muslim civilization to create a critical mass of notated musical documents using four different notational systems-Ottoman/Islamic, Byzantine, Ottoman/Armenian and Western. While modern musicologists have transcribed many items, the question of why such notated documents were created at all has barely been posed. Different forms of Ottoman/Islamic notation were invented by around 1700, and experiments were continued by Mevlevi dervish musicians until the very end of the eighteenth century. While Greek Orthodox cantors (psaltes) had employed their own notation to write down secular music already in the sixteenth century, this movement became more prevalent by the middle of the eighteenth century.

Could the introduction of notation have been caused by the influence of the West on an "Eastern" musical practice? By now this interpretation is belied by the fact that throughout the eighteenth century, Western staff notation was not employed by Ottoman musicians. The issue is somewhat confused because the earliest major document of notation of Ottoman music, the Mecmua-ı Saz ü Söz from around 1650, is indeed in Western notation. But-as recent work by Cem Behar and Judith Haug have shown the author, the converted Pole Ali Ufki/Bobowski employed his notation only for his own use at court and later as a pedagogic aid in teaching Ottoman music to European ambassadors and merchants. His notated documents were soon brought to France and England and had no effect within the Ottoman Empire itself.

Closely related forms of Ottoman/Islamic notation were invented around 1700 by the Mevlevi Dervish Nayi Osman Dede and by the Moldavian Prince Demetrius Cantemir. Experiments were continued by Mevlevi dervish musicians until the very end of the eighteenth century. Within the Ottoman court it would seem that the need for notation emerged from an internal development, while the talent of the Moldavian intellectual and musician Cantemir was appropriated to serve this internal need. Cantemir responded to an informal request by members of the court to create a new theory to explain the current state of Ottoman music, to which the musical notation was just auxiliary. But scholars have still been unable to solve the enigma of what relationship Cantemir's notation may have 
to Osman Dede's. While this question may not be crucial to the larger picture, we can simply observe that the two systems of notation are both based upon Arabic letters that symbolize the steps of the general scale of Ottoman music, especially as concretized on the neck of the lute tanbur of the late seventeenth century, plus Arabic numerals for duration. Osman Dede was almost a generation older than Cantemir, and they seem to have been aware of one another. The Mevlevi dervishes would appear to have possessed a cultural mechanism that ensured continuity of their artistic repertoire, at least since the beginning of the seventeenth century. The very strength of their internal musical pedagogy would seem to have obviated a specific need for musical notation for their ritual ayin. But, by the beginning of the eighteenth century, they evidently felt the need to utilize notation to preserve some parts of the secular, courtly repertoire.

Since the seventeenth century the Mevlevi dervishes had become the teachers to many of the Armenian, Greek, and Jewish musicians in Istanbul and Edirne. Hence, the Mevlevi dervishes allowed musicians of the various Christian and Jewish communities to participate in the musical system of the Ottoman/Islamic civilization. The Mevlevi dervishes of Istanbul constituted the most coherent group within Ottoman Muslim society that showed a consistent interest in musical notation from this generation on. Dervish Mustafa Kevseri employed Cantemir's notation approximately thirty to fifty years later for his own musical anthology. In 1794 Osman Dede's grandson, Abdülbaki Nasır Dede, created another musical notation based on the so-called ebced system (applying Arabic letters for notes of the general scale in the order in which they appear moving upward). In addition, he was the author of a major work of musical theory. Both Cantemir and the eighteenth-century Mevlevi musicians/scholars created their works for pedagogic purposes, but since none of them were printed in that century, their distribution was very small. When the French interpreter Charles Fonton visited Turkey in the 1750s, he could not even locate a copy of Cantemir's treatise or his notation. During this generation the Armenian Tanburi Harutin apparently created his own letter notation, but it was only at the end of the century and the beginning of the next that there was a significant notational initiative by Armenian musicians-influenced also by the Armenian 'renaissance' sponsored by the Armenian Catholic Church in Venice-culminating in the notation of Baba Hamparsum after $1813 .{ }^{21}$ It is only very recently that the question of the nature of the internal need that produced several forms of Ottoman musical notation has come up. These form part of the background to the current ongoing project at the Westphalian University in MünsterCorpus Musicae Ottomanicae. We are not yet in a position to integrate all the factors at play, but we can at least suggest the main lines of this development. These appear to transcend purely musical issues and involve several aspects of politics, society, and culture during this era.

\section{In Lieu of a Conclusion: The Eighteenth-Century Ottoman Synthesis}

By the turn of the eighteenth century this Ottoman musical 'renaissance' involved also musical theory and notation (with Osman Dede and Cantemir). A fuller development of the new conceptions of usul and melody emerged in the generation after Cantemir (with Zaharya, Haham Musi, et al.). This new music involved a synthesis of Persian, Turkic, and Byzantine elements. The entrance of non-Muslims-notably Greek cantors (psaltes)-into courtly composition and performance brought with them some techniques of Byzantine music, seen even two generations earlier in Itri's Naat-l Peygamberi. While Byzantine music lacks an usul system per se, it had a richly developed melodic line, which increased in complexity toward the end of the seventeenth century (e.g. Itri's contemporary, Petros Bereketis [1665-1725], who was evidently familiar with Ottoman music). The stylistic emphasis of Ottoman music was now on an inward turning fusion of secular and mystical styles, including secularized allusions to the music of the Greek church. At the same time the leading Greek church composers began to incorporate elements from secular Ottoman music. This became the musical manifestation of the "locally generated modernity" of the long eighteenth century-to which both Mevlevi dervishes and non-Muslim elites contributed-and left its imprint on Ottoman music throughout much of the nineteenth century as well. 